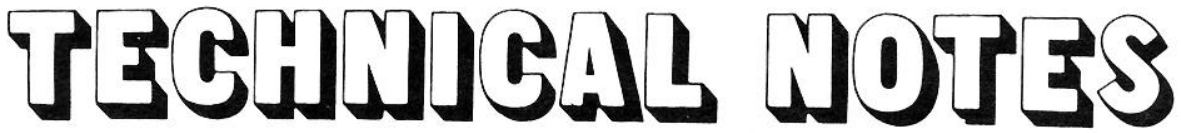

\section{Reseda lutea: A Multipurpose Plant for Arid and Semiarid Lands}

\section{R. MOGHADDAM}

Highlight: Reseda lutea is a plant well adapted to the arid and semiarid rangelands of Iran. It provides early spring green growth, is palatable to sheep and goats, and compares favorably with alfalfa in nutritive content.

Aridity of the climate is the most important factor in limiting plant growth and, therefore, forage production in arid and semiarid lands. Limited existing or potentially available water does not leave opportunity for forage production under irrigation, because other demands of the increasing population are expanding constantly. Also, the cost of hay produced under irrigation does not leave the alternative to increase irrigated forages for livestock needs; furthermore, sheep and goat raising can be reliable if the animals can take most of their nutritional needs from rangelands. The only solution to solving the problem of forage and meat production in arid and semiarid rangelands in areas such as Iran seems to be producing forage under dry farming.

For seeding programs each area has the opportunity to use introduced plants; however, there are also many native species which still exist in the natural vegetation that could be used for reseeding. According to my experience, Reseda lutea can be considered as one of the most useful and multipurpose plants for arid and semiarid rangelands.

\section{Growth Characteristics}

Reseda lutea is a plant of the Resedaceae family, which is a perennial with deep roots and many erect and very fast-growing stems, each terminating in a series of flowers, and which remains green during the summer. The flowers are very attractive to honey bees, more attractive than clover (Trifolium pratense) flowers. It is a very early-growing plant, and, according to our observations, is one of the earliest growing in arid and semiarid rangelands.

Phenological observations in 1975 on southern slopes of Albourn Ranges, Iran, at $1,300 \mathrm{~m}$ elevation, gave the following growth periods:

$\begin{array}{ll}\text { Growth started } & \text { March 15 } \\ \text { Flower buds forming } & \text { April 4 } \\ \text { Flowering began } & \text { April 18 } \\ \text { Flowering ended } & \text { June 2 } \\ \text { Seed ripening } & \text { June 14 } \\ \text { Growth ended } & \text { October 25 }\end{array}$

Comparing the beginning of growth of Reseda to other native species in the region, we observed an approximate 25-day interval in which Reseda produced forage ahead of the principal associated vegetation. Reseda lutea was $32.5 \mathrm{~cm}$ in height and in full fower on April 25; but the dominant species of the site, Stipa barbata, Artemisia herba-alba, and Salsola rigida, were in early growth. This early growth is very important, especially in mountainous regions or regions

The author is head, Department of Range and Watershed Management, College of Natural Resources, University of Tehran, Karadj, Iran.

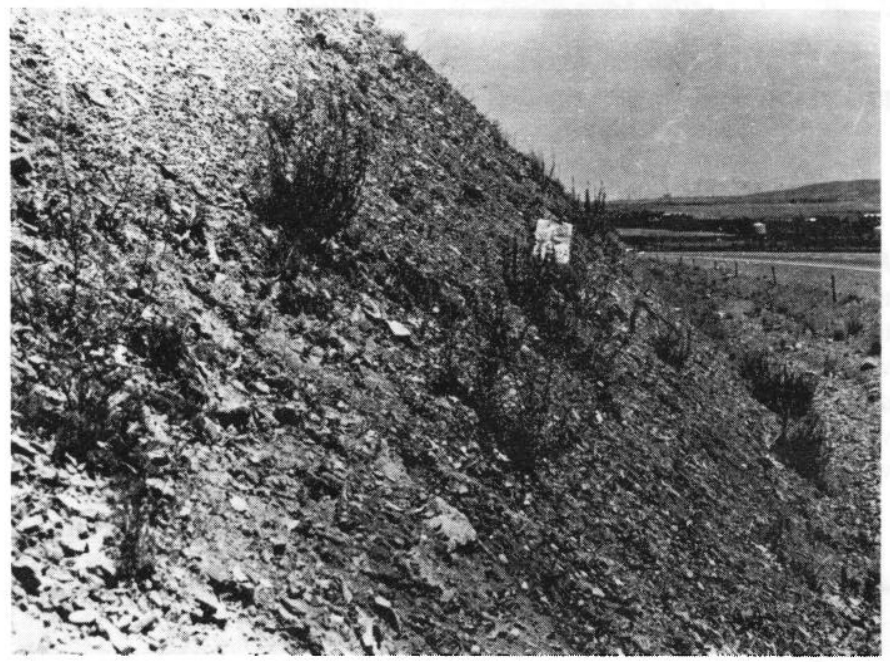

Fig. 1. Regeneration of Reseda lutea in difficult conditions, (near Karadj, Iran).

where there is a deficit of winter forage and the livestock suffer from shortages of forage during late winter and early spring.

Reseda produces considerable seeds, and the seeds germinate easily, even in very harsh conditions. The seedlings can become established under severe growing conditions. This can be observed from its distribution in Iran. It occurs in Iran from $100 \mathrm{~mm}$ annual precipitation in the northeast hills of Zahedan at 1,700 m elevation (Moghaddam 1975) to $400 \mathrm{~mm} 25 \mathrm{~km}$ south of Amol near the Caspian Sea at $300 \mathrm{~m}$ elevation (Moghaddam 1973).

The elevational distribution of Reseda ranges from $300 \mathrm{~m}$ south of Amol to $1,900 \mathrm{~m}$ in central Albourn. It survives well under extremes of temperatures, growing in northeast Zahedan, where temperatures can exceed $50^{\circ} \mathrm{C}$, as well as in the Karadj Region and Albourn Mountains, where winter temperatures may fall below $-25^{\circ} \mathrm{C}$ (Fig. $3)$.

Table 1. Chemical analysis of Reseda lutea and Medicago sativa grown at Karadj, Iran.

\begin{tabular}{llccccc}
\hline & & \multicolumn{5}{c}{ Constituent $(\%)^{1}$} \\
\cline { 3 - 7 } Species & Growth stage & DM & CP & CF & Ca & P \\
\hline Resedalutea & Pre-flowering & 18.8 & 17.5 & 23.6 & 2.5 & 0.27 \\
& Full flowering & 22.2 & 18.8 & 23.4 & 2.7 & 0.27 \\
& Seed stage & 31.1 & 16.1 & 43.4 & 1.9 & 0.22 \\
Medicago sativanyyyyyyyy & Pre-flowering & 20.6 & 24.6 & 13.8 & 2.3 & 0.30 \\
& Flowering & 27.9 & 16.8 & 28.6 & 2.4 & 0.15 \\
\hline
\end{tabular}

${ }^{1} \mathrm{DM}=$ dry matter; $\mathrm{CP}=$ crude protein; $\mathrm{CF}=$ crude fibers; $\mathrm{Ca}=$ calcium; and $\mathrm{P}=$ phosphorus. 


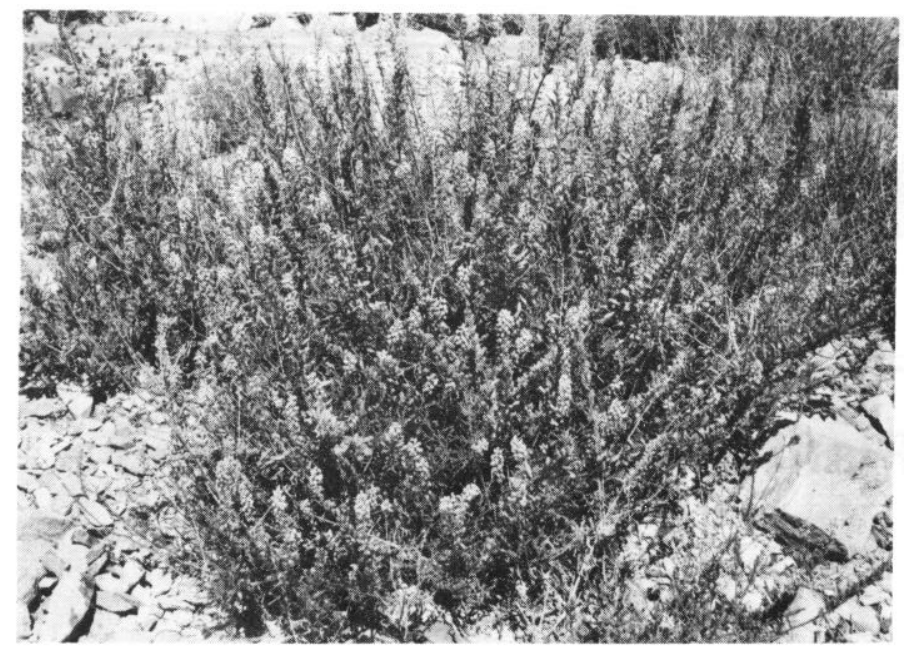

Fig. 2. Optimum growth of Reseda lutea at Karadj region, Iran.

\section{Forage Value}

According to data obtained from chemical analysis (Table 1), Reseda as compared with alfalfa (Medicago sativa) is high in nutritional value. The palatability of Reseda has been tested in feeding trials by range-grazed native sheep and goats, where it was compared with alfalfa (Medicago sativa) and crested wheatgrass (Agropyron desertorum). The green forage of the Reseda, alfalfa, and crested wheatgrass was cut into $5-\mathrm{cm}$ pieces and fed on the range. Samples were weighed before and after each trial and the percents consumed of
Table 2. Consumption of Reseda lutea, Medicago sativa, and Agropyron desertorum in feeding trials with sheep and goats on the range.

\begin{tabular}{lccc}
\hline & \multicolumn{2}{c}{ Weight $(\mathrm{kg})$} & $\begin{array}{c}\text { Percent } \\
\text { consumed }\end{array}$ \\
\cline { 2 - 3 } Species & Before & After & 40 \\
Reseda lutea & 3.50 & 2.10 & 28 \\
Medicago sativa & 5.00 & 3.60 & 18 \\
Agropyron desertorum & 8.08 & 6.60 & \\
\hline
\end{tabular}

each species were calculated (Table 2). More Reseda was taken than either the alfalfa or crested wheatgrass.

\section{Conclusion}

The characteristics of growth, establishment, adaptation, and palatability of Reseda lutea indicate it not only can be a very useful plant for grazing or hay production for winter times in harsh conditions of arid and semiarid rangelands, but it also has a potential as a plant for establishing or improving cover in watersheds and areas with severe erosion. It also should be a useful plant for revegetating road cuts, mining areas, and spoil banks. Its distribution in different conditions leaves the opportunity to use this plant not only in restoring natural vegetation in Iran, but in similar conditions in other countries.

It is rcommended that studies be undertaken about introduction of this plant into variable ecological conditions.

\section{Literature Cited}

Moghaddam, M. R. 1973. Introduction to range management. College of Natural Resources, Karaj, Iran.

Moghaddam, M. R. 1975. Vegetation condition in Sistan District and its depletion. Proceedings of the First Seminar on Problems of the Natural Vegetation of Iran, June 29-July 2, 1975. Tehran, Iran. 